\title{
SOCIAL VALUES, ECONOMIC FREEDOM AND ECONOMIC GROWTH. A COMPARATIVE ANALYSIS
}

Şerban OLAH ${ }^{1}$

DOI: https://doi.org/10.35782/JCPP.2021.4.08

\begin{abstract}
The objective of the article is the analysis of the relation between social values, economic freedom and economic growth. The first part explores the international empirical literature, the second part presents the main outputs of the statistical analysis. There are two statistical techniques used in the empirical analysis: the correlational analysis and the cross-country time series panel regression. The conclusion is that the poorer countries in the sample with lower scores of economic freedom and achievement motivation have a higher speed of economic growth. There is an indirect impact of the social values on the economic growth.
\end{abstract}

Keywords: economic growth, cross-country time series panel regression, economic freedom, materialist values, post-materialist values, achievement motivation.

\section{Introduction}

Since the work of Max Weber regarding the effect of the Protestant Ethic on the development of the Capitalism (Weber, 1904) many authors explored the relation between culture and economy. McClelland (1961) wrote about the achievement motivation theory, starting from the Weberian thesis, but he then focused on the values that parents, schools and other agents of socialization brought to children (Granato, Inglehart and Leblang, 1996). The debate started by Weber and McClelland continued with the scientific contributions Hofstede, Schwartz (1994), and Inglehart (2019).

The cultural foundation and the culture are words rooted in cultural anthropology and they include values, ideas and other symbolic systems that shape behaviour and are transmitted across generations (Kroeber and Kluckhohn, 1952). It is important to mention that the word "culture" has been used by Cicero in "Tusculanae Disputationes" (45 AC) in the sense of the cultivation of the philosophic spirit. Until the 17th and 18th

$1 \mathrm{PhD}$, Associate Professor, University of Oradea, Romania, Department of Sociology and Social Work, e-mail: serbanolah2002@yahoo.com 
centuries, culture reflected the intellectual and the moral development of the humans at a personal level. In those centuries, the meaning of the word has been extended for expressing not only the development of the human as individual, but also that of the entire society (Petrakis, 2014).

The idea that the relation between social values and economic growth is mediated by institutions and economic freedom can be found in works of Johnson and Lenartowicz (1998), Williamson and Mathers (2011), Jordaan and Dima (2020) and Jora et al. (2020). In addition to standard economic variables such as physical capital, human capital and innovation, non-standard variables such as geographic latitude, institutions, culture and social capital are considered important factors in explaining economic success (Roşca, 2020). In "The Economics of Growth", Aghion and Howitt (2009) concluded that the exploration of economic growth arrived in an unmarked territory; culture was identified as a key variable that economists should focus on (Petrakis, 2014; Roşca, 2018).

The question why some countries are poor and others rich attracted scientists ever since Montesquieu (1748) and Smith (1777). The articles and books on this topic could be divided into two groups. One, represented by the development economists who proposed several economic, political and geographical determinants but rejected the importance of culture, such as Gallup and Sachs (1998) or Solow (1956); and a second, consisting of sociologists, political scientists or anthropologists such as Harrison (1992), Harrison and Huntington (2000) or McClelland (1961), who believe that the cultural values determine differences not only in geopolitical economic development, but also in terms of business development (Copuš and Čarnogurský, 2017; Minkov and Blagoev, 2009).

On the other hand, the idea that economic growth was influenced by cultural factors led to a high degree of resistance from several scientists. A reason of this resistance is the fact that cultural values have been perceived by many scientists as loose and also as permanent characteristics of societies (Granato et al., 1996). Dieckmann (1996) used a regression analysis on 60 countries and concluded that the Hofstede index of uncertainty avoidance is significantly correlated with economic growth. Using the data from the World Value Survey and the Levine and Renelt (1992) data set, Granato et al. (1996) tested the hypothesis that cultural attitude which is favorable to achievement and saving has a positive effect on economic growth, while the post-materialist cultural has a negative effect. They found that the cultural factors have an influence on economic growth. Petrakis and Kostis (2013) used a panel regression on 41 countries to find out social orientation (an index based on four variables: gender equality, in-group collectivism, institutional collectivism and human orientation) has a positive influence on the annual rate of economic growth.

Freedom is one of the core problems of the humankind. Hayek (1960) considered freedom as a situation in which the human is not the subject of the arbitrary will's coercion. Even in the age of Adam Smith, economists argued that freedom to choose, supply freedom, the business competition, or the trade and the safety of private property are central ingredients of economic progress. On the other side, some economic historians such as North and Thomas (1973) emphasized the role of property rights regarding long time economic growth (de Haan and Siermann, 1998). 
118 | Social values, economic freedom and economic growth. a comparative analysis

If older articles such as those of Dollar (1992) and Sachs and Warner (1995) discovered a positive and powerful correlation between economic freedom and economic growth, Johnson and Lenartowicz (1998) consider that the relation between these variables is rather loose, when other variables enter the regression model. De Haan and Siermann (1998) examined the robustness of the relation between economic freedom and economic growth, concluding that the link between these variables depends on the type of measure used: for some indicators of freedom there is a direct and robust relation, while for others not. Justesen (2008) used a Granger causality test on a panel data from 1970-1999, concluding that some, but not all elements of the composite index of economic freedom influence economic growth and investment. Cebula and Clark (2012) explored the impact of the 10 indicators of economic freedom using the Heritage database for the OECD countries. Working with panel data and Random Effects Model, they found that the relation is positive and significant for only 7 of 10 indicators of economic freedom. Doucouliagos and Ulubasoglu (2006) have done a meta-analysis of the papers on the relation between economic freedom and economic growth, identifying that 33 of 52 articles used the Fraser Institute's composite index of freedom, and 19 other databases such as Heritage Foundation, Freedom House or Scully and Slotje. Doucouliagos and Ulubasoglu have done their own research on this topic on a sample of 82 countries and found a positive direct association between these variables and an indirect effect of the economic freedom when physical capital was entered in the regression model.

Johnson and Lenartowicz (1998) used a cross-country time series panel regression and a correlational analysis on 49 countries, finding out that economic progress depends on economic freedom. There is a positive and powerful association between economic freedom and economic growth, between economic freedom and low uncertainty avoidance and between economic freedom and high levels of autonomy. Williamson and Mathers (2011) found that both culture and economic freedom are important in explaining economic prosperity, but the power of the impact could be better understood if both variables entered the regression model. They also found that economic freedom is more important than culture in explaining economic growth. Jordaan and Dima (2020) analyzed the effect of post-materialism on economic development. They concluded that institutions are the channels of transmission for the indirect effects of social values. Both post-materialism and institutions generate important effects on economic development.

\section{Methodology and Discussions}

The objective of this paper is to test the relation between social values, economic freedom and economic growth. It is believed that social values have an indirect influence on economic growth. The social values influence the economic growth through different institutional channels. There are direct linkages between the social values and economic freedom and between economic freedom and economic growth.

The research hypotheses are:

H1: There is a direct and positive correlation between masculinity and economic freedom. 
H2: There is a direct and positive correlation between individualism and economic freedom.

H3: There is a positive and direct correlation between uncertainty avoidance and economic freedom.

H4: There is a direct and negative correlation between power distance and economic freedom.

H5: There is a direct and positive correlation between the post-materialism score and economic freedom.

H6: There is a direct and positive correlation between achievement motivation and economic freedom.

H7: There is a direct association between economic freedom and economic growth.

The sample used consisted of 33 countries from different continents: Argentina, Australia, Brazil, Chile, China, Columbia, Ecuador, Egypt, Germany, Ghana, India, Japan, Jordan, Malaysia, Mexico, Morocco, the Netherlands, New Zeeland, Nigeria, Peru, the Philippines, Romania, Russia, Singapore, South Africa, South Korea, Spain, Sweden, Thailand, Turkey, Ukraine, the United States of America, and Uruguay. Table 1 presents the variables used in the statistical analysis.

Table 1: The description of the variables used in the statistical analysis

\begin{tabular}{|l|l|}
\hline \multicolumn{1}{|c|}{ Variables } & \\
\hline GDP annual growth rate & Numerical variable \\
\hline Economic Freedom & Numerical variable \\
\hline GDP per capita & Numerical variable \\
\hline Power Distance & Numerical variable \\
\hline Individualism & Numerical variable \\
\hline Masculinity & Numerical variable \\
\hline Uncertainty Avoidance & Numerical variable \\
\hline Long Term Orientation & Numerical variable \\
\hline Post - Materialism & Numerical variable \\
\hline Inglehart score & Numerical variable \\
\hline
\end{tabular}

Source: author's own work

The first statistical technique used was the correlational analysis. STATA 13 was the software used for all the statistical analyses. The Pearson correlational coefficient (that could take values between -1 and +1 ) was used for the correlational analysis. Tables 2 and 3 depict the linkages between Hofstede's social values and the composite index of economic freedom for a time series between 1995 and 2015. Individualism, masculinity, power distance and uncertainty avoidance have been computed using the www.hofstede-insights.com website, while the composite index of economic freedom was computed using the Heritage Foundation's data base. 
120 | Social values, economic freedom and economic growth. a comparative analysis

Table 2: The correlational matrix between Hofstede's social values and economic freedom (1995)

\begin{tabular}{|c|c|c|c|c|c|c|}
\hline Variables & (1) & (2) & (3) & (4) & (5) & (6) \\
\hline (1) ln_Economic Freedom_1995 & 1.000 & & & & & \\
\hline (2) Power Distance & -0.572 & 1.000 & & & & \\
\hline (3) Individualism & 0.336 & -0.747 & 1.000 & & & \\
\hline (4) Masculinity & 0.149 & 0.041 & 0.016 & 1.000 & & \\
\hline (5) Uncertainty Avoidance & -0.275 & 0.132 & -0.270 & -0.050 & 1.000 & \\
\hline (6) Long Term Orientation & 0.114 & -0.069 & 0.118 & -0.056 & -0.063 & 1.000 \\
\hline
\end{tabular}

Table 3: The correlational matrix between Hofstede's social values and economic freedom (2015)

\begin{tabular}{|c|c|c|c|c|c|c|}
\hline Variables & (1) & (2) & (3) & (4) & (5) & (6) \\
\hline (1) ln_Economic Freedom_2015 & 1.000 & & & & & \\
\hline (2) Power Distance & -0.469 & 1.000 & & & & \\
\hline (3) Individualism & 0.349 & -0.747 & 1.000 & & & \\
\hline (4) Masculinity & -0.026 & 0.041 & 0.016 & 1.000 & & \\
\hline (5) Uncertainty Avoidance & -0.291 & 0.132 & -0.270 & -0.050 & 1.000 & \\
\hline (6) Long Term Orientation & 0.162 & -0.069 & 0.118 & -0.056 & -0.063 & 1.000 \\
\hline
\end{tabular}

Comparing the results in Tables 2 and 3, a positive correlation between individualism and economic freedom can be noticed, as well as between long term orientation and economic freedom. Negative correlation scores exist between power distance and economic freedom, and also between uncertainty avoidance and economic freedom. The highest positive correlation seems to be between individualism and economic freedom. The correlational matrixes between economic freedom, the post-materialism score, the Inglehart score and the achievement motivation can also be noticed. Output values are presented for a time series between 1995 and 2015. The post-materialism score, the Inglehart score and the achievement motivation score have been computed using databases from the World Values Survey (3rd and 6th waves). The composite index of economic freedom has been computed using the Heritage Foundation's database. The achievement motivation score was computed from the World Value Survey's dataset. A question in WVS asked whether "There is a list of qualities that children are encouraged to learn at home. Which one you consider to be especially important?" The list contains qualities such as autonomy, economic realization, saving and determination. Other items from the list emphasize the conformity to the social traditional norms, such as obedience and religious belief. The achievement motivation score was computed using the percentages for each country emphasizing autonomy and saving minus the percentages emphasizing obedience and religious belief (Granato et al., 1996).

We have to add that post-materialism is the percentage of those individuals that have post-materialist values and the Inglehart score is the average score of the materialist, post-materialist and mixed values from all the countries in the used sample. 
Table 4: Correlational matrix between achievement motivation, Inglehart score, postmaterialism score and economic freedom (1995)

\begin{tabular}{|l|c|r|r|r|}
\hline \multicolumn{1}{|c|}{ Variables } & (1) & (2) & \multicolumn{1}{c|}{ (3) } \\
\hline (1) In_Economic Freedom_1995 & 1.000 & (4) \\
\hline (2) Post Materialism & 0.296 & 1.000 & 1.000 & \\
\hline (3) Inglehart_score & 0.115 & 0.691 & 0.160 & 1.000 \\
\hline (4) Achievement_Motivation & 0.373 & 0.135 & Source: author's own work
\end{tabular}

Table 5: Correlational matrix between achievement motivation, Inglehart score, postmaterialism score and economic freedom (2015)

\begin{tabular}{|l|c|r|r|r|}
\hline \multicolumn{1}{|c|}{ Variables } & (1) & (2) & (3) & \multicolumn{1}{c|}{ (4) } \\
\hline (1) In_Economic Freedom_2015 & 1.000 & 0.337 & 1.000 & \\
\hline (2) Post Materialism & 0.241 & 0.691 & 1.000 & \\
\hline (3) Inglehart_score & 0.311 & 0.135 & 0.160 & 1.000 \\
\hline (4) Achievement_Motivation & \multicolumn{4}{|c}{ Source: author's own work }
\end{tabular}

Tables 4 and 5 indicate a positive correlation between achievement motivation and economic freedom and also between post-materialism and economic freedom. The highest positive correlation coefficient seems to be between achievement motivation and economic freedom. The research also wanted to know if economic freedom had an influence on economic growth, reason why a cross country time series panel regression has been carried out with the sample presented at the beginning of the methodology. The data used in the regression model was computed using www.ourworldindata.com (the annual rate of GDP per capita and the annual rate of economic growth) and the Heritage Foundation database (for the composite index of the economic freedom). A balanced static linear panel model was also used (dataset in which each panel member is observed every year). It also has to be added that the natural logarithms for the independent variables were computed, as they reduce extreme scores and normalize the distribution (Field, 2016). Table 6 presents the main results of the panel regression model.

As per Table 6, the random effect model is accepted because the null hypothesis of the Hausman test is accepted (Chi2 $=2.38$, $\mathrm{p}$-value $=0,303)$. It can be noticed that economic freedom and economic growth are negatively, as well as the initial GDP per capita and the economic growth. The annual GDP growth rate is higher in the case of the less developed economies. This might be understood as a tendency of the less developed economies to grow at a higher speed than more developed ones. If all the correlational analyses and panel regression results are analyzed, it can be concluded that the social values indirectly influence economic growth by using institutional chains. The social values are significantly correlated with economic freedom, while economic freedom is a significant predictor of economic growth. 
122 | Social values, economic freedom and economic growth. a comparative analysis

Table 6: The main results of the panel regression model

\begin{tabular}{|c|c|c|c|c|c|c|c|c|}
\hline GDP_GR & Coef. & St.Err. & z-value & p-value & \multicolumn{2}{|c|}{$[95 \%$ Conf } & Interval] & Sig \\
\hline Ln_EF & -3.315 & 1.663 & -1.99 & 0.046 & & -6.57 & -0.54 & ** \\
\hline Ln_GDP & .8905 & 0.411 & 2.15 & 0.030 & & 0.084 & 1.696 & ** \\
\hline Ln_GDP_95 & -1.066 & 0.432 & -2.45 & 0.014 & & 1.913 & -0.218 & ** \\
\hline Constant & 17.64 & 5.629 & 3.13 & 0.002 & & 6.609 & 28.675 & $\begin{array}{c}* * \\
*\end{array}$ \\
\hline \multicolumn{2}{|c|}{ Mean dependent var } & 2.596 & \multicolumn{3}{|c|}{ SD dependent var } & & 3.726 & \\
\hline \multicolumn{2}{|l|}{ R-squared } & 0.038 & \multicolumn{3}{|c|}{ Number of obs } & & 692 & \\
\hline \multicolumn{2}{|l|}{ F-test } & 14.14 & \multicolumn{3}{|c|}{ Prob $>F$} & & 0.000 & \\
\hline \multicolumn{2}{|c|}{ Akaike crit. (AIC) } & 3659.811 & \multicolumn{3}{|c|}{ Bayesian crit. (BIC) } & & 3673.430 & \\
\hline \multicolumn{2}{|l|}{ Hausman Test } & Chi2 $=2.38$ & \multicolumn{3}{|c|}{ Prob $>$ chi2 $=0.303$} & & & \\
\hline \multirow{2}{*}{\multicolumn{2}{|c|}{$\begin{array}{l}\text { Breusch-Pagan Test } \\
\text { Model }\end{array}$}} & $\mathrm{BP}=75.02$ & \multirow{2}{*}{\multicolumn{3}{|c|}{$\mathrm{p}$-value $<2.2 \mathrm{e}-16(0.000)$}} & & & \\
\hline & & andom Effects & & & & & & \\
\hline
\end{tabular}

Source: author's own work

The speed of economic growth is higher in the case of the less developed countries and lower for the most developed countries. The lower the economic freedom, the higher the speed of the economic growth. Another finding is that economic freedom is higher in the countries that have higher scores for individualism, long term orientation, postmaterialism and achievement motivation. But higher scores for these social values mean that the country is highly developed. The conclusion is that social values change when countries obtain higher scores for GDP per capita. Economic freedom scores increase as the GDP per capita increases.

\section{Limitations}

The first limitation of this research is the use of GDP per capita as dependent variable. Many authors underlined the idea that GDP per capita is not the best way to measure for economic growth; in United Kingdom and France, politicians such as Tony Blair, David Cameron or Nicolas Sarkozy shaped their discourses around projects for measuring wellbeing not only by economic growth (Pilling, 2020). Another limitation is that the causal model used hasn't got more independent variables. More variables could probably increase the variance of the model (R-squared). A third limitation is the use of a static linear panel regression model. For future research, the dynamic panel regression might be better suited. Finally, the choice of countries in the sample might as well be a limitation. More countries would have been selected, had there been more statistical information for each year of the time series.

\section{Acknowledgements}

This study has no financial support from any institution whatsoever. 


\section{Funding}

The author received no financial support for the research, authorship, and/or publication of this article.

\section{Declaration of conflicting interests}

The author declares no conflicting interests.

\section{References}

Aghion, P., \& Howitt, P. P. (2009). The Economics of Growth. Cambridge: MIT Press.

Cebula, R. J., \& Clark, J. R. (2012). Lessons from the experience of OECD nations on macroeconomic growth and economic freedom, 2004-2008. International Review of Economics, 59(3), 231-243.

Copuš, L., \& Čarnogurský, K. (2017). Intercultural marketing: Culture and its influence on the efficiency of Facebook marketing communication. Management \& Marketing. Challenges for the Knowledge Society, 12(2), 189-207.

Dieckmann, O. (1996). Cultural determinants of economic growth: Theory and evidence. Journal of Cultural Economics, 20(4), 297-320.

Dollar, D. (1992). Outward-oriented Developing Economies Really Do Grow More Rapidly: Evidence from 95 LDCs, 1976-1985. Chicago, IL: The University of Chicago Press.

Doucouliagos, C., \& Ulubasoglu, M. A. (2006). Economic freedom and economic growth: Does specification make a difference?. European Journal of Political Economy, 22(1), 60-81.

Field, A. (2016). An Adventure in Statistics. London: Sage Publications Ltd.

Granato, J., Inglehart, R., \& Leblang, D. (1996). The effect of cultural values on economic development: theory, hypotheses, and some empirical tests. American Journal of Political Science, 40(3), 607-631.

De Haan, J., \& Siermann, C. L. (1998). Further evidence on the relationship between economic freedom and economic growth. Public Choice, 95(3), 363-380.

Gallup, J., \& Sachs, J. (1998). Location, location. Harvard International Review, 21(1), 5661.

Harrison, L. E. (1992). Who prospers: How cultural values shape economic and political success. New York, NY: Basic Books.

Harrison, L. E., \& Huntington, S. P. (2000). Culture matters: How values shape human progress. New York, NY: Basic Books.

Hayek, F. (1960). The Constitution of Liberty. Chicago, IL: University of Chicago Press.

Inglehart, R. (2019). Evoluţia culturală. Cluj-Napoca: Editura Şcoala Ardeleană.

Johnson, J. P., \& Lenartowicz, T. (1998). Culture, freedom and economic growth: do cultural values explain economic growth?. Journal of World Business, 33(4), 332-356.

Jora, O. D., Apăvăloaei, M. A., Stamate-Ştefan, A., Roşca, V. I., \& Gherghina, R. (2020). "Citadel of Science" and "Cathedral of Conscience": The University, As Institution, Was Born To Be Concerned With Sustainable Knowledge, Long 
124 | Social values, economic freedom and economic growth. a comparative analysis

Before Sustainability Became a Universal Concern. Amfiteatru Economic, 22(54), 312-329.

Jordaan, J. A., \& Dima, B. (2020). Post Materialism and Comparative Economic Development: Do Institutions Act as Transmission Channel?. Social Indicators Research, 148, 441-472.

Justesen, M. (2008). The effect of economic freedom on growth revisited: New evidence on causality from a panel of countries 1970-1999. European Journal of Political Economy, 24, 642-660.

Kroeber, A. L., \& Kluckhohn, C. (1952). Culture: A Critical Review of Concepts and Definitions. Peabody Museum, Cambridge, MA.

Levine, R., \& Renelt, D. (1992). A Sensitivity Analysis of Cross Country Growth Regressions. American Economic Review, 82(4), 942-963.

McClelland, D. C. (1961). The Achieving Society. New York: The Free Press.

Minkov, M., \& Blagoev, V. (2009). Cultural values predict subsequent economic growth. International Journal of Cross Cultural Management, 9(1), 5-24.

Montesquieu, C. (1748). De l'esprit des lois. Barrillot \& Fils, Genève.

North, D., \& Thomas, R. (1973). The Rise of the Western World. Cambridge: Cambridge University Press.

Petrakis, P.E, \& Kostis, P.C. (2013). Economic Growth and Cultural Change. Journal of Socioeconomics, C(47), 147-157.

Petrakis, P. (2014). Culture, Growth and Economic Policy. Springer Verlag, Berlin/ Heidelberg.

Pilling, D. (2020). Creșterea economică, o amăgire: Bogăția, sărăcia și bunăstarea națiunilor. Bucureşti: Editura Curtea Veche.

Roşca, V. I. (2018). Theoretical Considerations on the Evolution of Sombart's CenterPeriphery Model. Review of International Comparative Management, 19(1), 77-87.

Roşca, V. I. (2020). Implications of Lewin's field theory on social change. In: Proceedings of the International Conference on Business Excellence (Vol. 14, No. 1, pp. 617-625).

Sachs, J., \& Warner, A. (1995): Natural Resource Abundance and Economic Growth. National Bureau of Economic Research, Working Paper 5398, 1-54.

Schwartz, S. (1994). Are there universal aspects in the content and structure of values?. Journal of Social Issues, 50(4), 19-45.

Smith, A. (1777). An Inquiry into the Nature and Causes of the Wealth of Nations. W. Strahan and T. Cadell, London.

Solow, R. M. (1956). A contribution to the theory of economic growth. The Quarterly Journal of Economics, 70(1), 65-94.

Weber, M. (1904). Die protestantische Ethik und der „Geist“ des Kapitalismus. Archiv für Sozialwissenschaft und Sozialpolitik, 20, 1-54.

Williamson, C. R., \& Mathers, R. L. (2011). Economic freedom, culture, and growth. Public Choice, 148(3-4), 313-335.

***http://www.ourworldindata.org

$* * *$ http://www.heritage.org

$* * *$ www.hofstede-insights.com

$* *$ http://worldvaluesurvey.org 